\title{
OS SISTEMAS DE AVALIAÇÃO DA PROVA E O PROCESSO PENAL BRASILEIRO
}

\section{Érica de Oliveira Hartmann}

Mestranda em Direito Processual Penal na UFPR.

\begin{abstract}
SUMÁRIO: Introdução; 1 Os sistemas de avaliação da prova; 1.1 Fase religiosa ou mística; 1.2 Fase da tarifa legal ou da certeza moral do legislador; 1.3 Fase sentimental ou da certeza moral do juiz; 1.4 Fase científica; 2 O sistema de avaliação da prova adotado no processo penal brasileiro; Conclusão; Referências bibliográficas.
\end{abstract}

\section{INTRODUÇÃO}

O exato conhecimento da realidade em que se vive é sempre fundamental para que se possa dela fazer parte, e também para que se possa modificá-la, na medida em que transformações forem se mostrando necessárias. E essa exata percepção da realidade deve preocupar a todos nos mais diferentes ramos da vida. No Direito, não é diferente. Apenas as construções teóricas sobre determinado tema não significam que nelas estão contidas a exata dimensão da realidade em que se vive. Muitas vezes é somente através das construções jurisprudenciais que alguns temas jurídicos se tornam claros e, principalmente, é somente através da realidade social que o Direito se modifica, transforma-se. Por estas, e também por outras razões, é preciso efetivamente conhecêla.

Uma das questões obscuras dentro do sistema processual penal brasileiro (ao menos são poucos os autores que ousam dizer o contrário) é com relação aos sistema de avaliação das provas adotado pelo ordenamento jurídico brasileiro. A proposta do presente trabalho consiste, exatamente, em se descobrir (ou tentar descobrir) qual dos sistemas de avaliação da prova efetivamente vigora no processo penal brasileiro.

Para isso, faz-se necessário primeiro analisar, ainda que de maneira superficial (apenas explicitando suas características principais), os diversos sistemas (ou fases) de valoração das provas no processo que apareceram durante toda a história da humanidade. Após uma breve descrição de todas elas (fase religiosa, fase da tarifa legal, fase sentimental e fase científica) e a partir da análise dos textos legais (especialmente o Código de Processo Penal e a Constituição Federal), o que se procurará fazer é, como dito, definir qual o sistema (ou sistemas) que realmente prevalece $(\mathrm{m})$ no processo penal brasileiro, ou ao menos fazer ver se há um sistema único, puro, no sentido kantiano, para que se possa, com isso, partir para um estudo mais aprofundado do sistema processual adotado, sem estar à mercê das falácias doutrinárias que não raro aparecem diante de todos os operadores do Direito. 


\section{OS SISTEMAS DE AVALIAÇÃO DA PROVA}

\subsection{Fase religiosa ou mística}

A par de alguns entendimentos sobre a efetiva existência de uma fase anterior a esta, uma fase chamada de primitiva, ${ }^{1}$ na qual, de fato, não se podia falar em um sistema probatório, devido à precariedade da organização das sociedades, muitos autores concordam que esta fase religiosa é a primeira forma de análise de provas que surge na história da humanidade, ainda que para alguns não se configure como um verdadeiro sistema de avaliação da prova, mas sim meio de prova.

Tal fase foi influenciada preponderantemente pelo direito dos povos germânicos (aqui não se percebia, ainda, a ligação com a religião), e verificada especialmente na Idade Média, com grande influência religiosa (antes estes meios de prova também foram utilizados pelos povos hebreus, gregos, hindus e egípcios). Era baseada na crença de que "Deus interfere para dar razão a quem tem", 2 fazendo prevalecer a verdade e a justiça. Resta patente a grande influência da ignorância e do fanatismo religioso da época.

Era compreendida pelos chamados juízos de Deus, os quais poderiam se realizar através de três formas de processo: ordália (destinadas, em regra, aos vassalos), duelo - duellum-bellum (destinado aos cavaleiros) e juramento - Deus também punia o perjúrio (destinado geralmente aos senhores feudais).

As principais ordálias, as mais conhecidas, segundo HELIO TORNAGHI, ${ }^{3}$ eram a prova da fogueira, a prova do pão e do queijo, a prova da cruz, a prova da água fria e a prova da água quente e do ferro em brasa. Os duelos, fundamentados na admiração do povo pela coragem e bravura, podiam se travar entre as partes, entre uma testemunha do processo e aquele que havia impugnado o seu testemunho e ainda entre o acusado e os juízes (antes ou depois da sentença) para que aquele pudesse provar sua inocência. Como repreensão à grande quantidade dos juramentos falsos, implantou-se, na época, a instituição dos conspurgadores, que "consistia no juramento de outras pessoas em abono da pessoa que prestava juramento". ${ }^{4}$

\subsection{Fase da tarifa legal ou da certeza moral do legislador}

Esta fase é reconhecida pela maioria absoluta dos autores (com exceção, por exemplo, de HELIO TORNAGHI) como o primeiro sistema de avaliação da prova. ${ }^{5}$ Todavia, pretende-se que fique bastante claro que não está a se apresentar, aqui, os

1 Sobre o tema, ver NILO BAIRROS DE BRUM, em Requisitos retóricos da sentença penal, p. 55.

2 TORNAGHI, Helio. Instituições de processo penal. Rio de Janeiro: Forense, v. IV, 1959, p. 210.

3 TORNAGHI, Helio. Instituições de processo penal. ..., v. IV, p. 210-211.

4 SANTOS, Moacyr Amaral. Primeiras linhas de direito processual civil. São Paulo: Saraiva, v. II, 1985 , p. 382.

5 TORNAGHI, Helio. Instituições de processo penal. ..., v. IV, p. 212. 
sistemas em ordem cronológica, posto que não há unanimidade entre os autores sobre a efetiva e correta seqüência temporal de tais sistemas.

Segundo esse sistema, cada prova tem um valor certo e constante, predeterminado pelo legislador, sendo defeso ao juiz valorar as provas de acordo com seus critérios pessoais e subjetivos, que afronte o que foi determinado pela lei. Existia uma hierarquia nítida entre as provas. Havia, conforme aduz NILO BAIRROS DE BRUM, ${ }^{6}$ "tabelas prévias de valoração das provas. Dependendo da natureza do fato ou da qualidade da pessoa acusada, a lei previa o tipo e a qualidade de provas que deveriam ser consideradas pelo juiz". Essas regras de apreciação da prova, ressalta JORGE DE FIGUEIREDO DIAS, ${ }^{7}$ eram baseadas em regras da vida e da experiência que eram tidas tradicionalmente como seguras pela sociedade.

Para HELIO TORNAGHI, vale ressaltar, "o sistema das regras legais não é inerente à forma inquisitória, mais foi no processo inquisitório medieval que teve mais largo desenvolvimento". ${ }^{8}$ Mas por que no processo inquisitório? Porque em tal sistema se desconfiava do julgador, e o legislador, de antemão, determinava a hierarquia entre as provas, que fundaria a estrutura do julgamento. Como o acusado era bastante exposto ao inquisidor, retirava-se dele a tarefa de avaliar, valorar a prova, a responsabilidade caso houvesse avaliado, pois estava tudo predeterminado.

O fundamento da adoção deste sistema por muitos ordenamentos jurídicos, segundo JACINTO NELSON DE MIRANDA COUTINHO, ${ }^{9}$ baseava-se no fato de que "muitas legislações aceitaram a previsão da possibilidade de o juiz incorrer em erro, no momento de valoração dos meios de prova utilizados, razão pela qual se fixou, na lei, uma hierarquia de valores referentes a tais meios. Veja-se, neste sentido, o sistema processual inquisitório medieval, no qual a confissão, no topo da estrutura, era considerada prova plena, a rainha das provas (regina probationum), tudo como fruto do tarifamento previamente estabelecido. Transferia-se o valor do julgador à lei, para evitar-se manipulações; e isso funcionava, retoricamente, como mecanismo de garantia do argüido, que estaria protegido contra os abusos decorrentes da subjetividade. Sem embargo, a história demonstrou, ao revés, como foram os fatos retorcidos, por exemplo, pela adoção irrestrita da tortura". ${ }^{10}$

Exemplo da tarifação era o fato de que, segundo narra OVÍDIO BAPTISTA DA SILVA, ${ }^{11}$ o depoimento de um servo não tinha, em absoluto, o mesmo valor do

6 BRUM, Nilo Bairros de. Requisitos retóricos da sentença penal. São Paulo: Revista dos Tribunais, 1980, p. 55.

7 DIAS, Jorge de Figueiredo. Direito processual penal. Coimbra: Coimbra Editora, v. I, 1981, p. 199.

8 TORNAGHI, Helio. Instituições de processo penal. ..., v. IV, p. 215.

9 COUTINHO, Jacinto Nelson de Miranda. Introdução aos princípios gerais do processo penal brasileiro. In: Revista da Faculdade de Direito. Curitiba: UFPR, ano 30, n. 30, p. 196, 1998.

10 Neste mesmo sentido, ver: DIAS, Jorge de Figueiredo. Direito processual penal. Coimbra: Coimbra Editora, 1981, p. 199.

11 BAPTISTA DA SILVA, Ovídio. Curso de processo civil. São Paulo: Saraiva, v. I, 2000, p. 348. 
depoimento de um nobre. Entretanto, o depoimento de dez servos equivalia ao depoimento de um nobre ou o de um senhor feudal. E o juiz deveria assim considerar, ainda que estivesse convencido de que o nobre tivesse mentido e o servo não. Outras regras ainda eram bem conhecidas: testis unus testis nulus, testibus duobus fide dignis credentum, entre outras.

O juiz, então, não passava de sujeito passivo, ao qual incumbia somente reconhecer na sentença o valor predeterminado pela lei a cada prova produzida sem que pudesse apreciar tais provas de acordo com a sua conviç̧ão. Nas palavras de MOACYR AMARAL SANTOS, ${ }^{12}$ "no sistema da prova legal, a instrução probatória se destinava a produzir a certeza legal. O juiz não passava de um mero computador, preso ao formalismo e ao valor tarifado das provas, impedido de observar positivamente os fatos e constrangido a dizer a verdade conforme ordenava a lei que o fosse. No depoimento de uma só testemunha, por mais idônea e verdadeira, haveria apenas prova semiplena, enquanto que nos de duas testemunhas, concordes e legalmente idôneas, ainda que absurdos os fatos narrados, resultaria prova plena e, pois, certeza legal". ${ }^{13}$

A prevalência deste sistema deu-se, sobretudo, no processo inquisitório. Vale ressaltar que, ao mesmo tempo em que o juiz (inquisidor) estava preso à prévia valoração das provas, ele era, antes de tudo, o gestor das provas. "O sistema inquisitório, regido pelo princípio inquisitivo, ${ }^{14}$ tem como principal característica a extrema concentração de poder nas mãos do órgão julgador, o qual detém a gestão da prova. Aqui, o acusado é mero objeto de investigação e tido como detentor da verdade de um crime, da qual deverá dar contas ao inquisidor". ${ }^{15}$

Uma das grandes críticas feitas a esse sistema está no fato de que, ante a obrigatoriedade de decidir segundo os valores das provas anteriormente estabelecidos pelo legislador, o juiz deveria, em algumas situações, decidir contra aquilo que podia entender ser a verdade. Neste sentido, afirma OVÍDIO BAPTISTA DA SILVA:16 "o juiz, segundo este sistema, deverá decidir rigorosamente com base no que foi alegado e provado pelas partes ..., embora sua convicção pessoal sobre aquilo que fora provado nos autos the indique que a prova produzida não retrata a verdade".

Apesar de apontar o mesmo defeito do sistema acima mencionado, HELIO TORNAGHI alerta "que o inconveniente do sistema das provas legais não está na adoção de regras de avaliação da prova, mas na imposição delas ao juiz. Nenhum estorvo existe em que elas sejam propostas, como regras técnicas, não impostas como regras jurídicas. Os preceitos que formam o arcabouço deste sistema são o resultado de longa observação, cristalizam grande experiência e estão impregnados daquela sabedoria

12 SANTOS, Moacyr Amaral. Primeiras linhas de direito processual civil. ..., v. II, p. 382.

13 Sobre prova plena e semiplena, ver, por exemplo: MALATESTA, Nicola Framarino Dei. A lógica das provas em matéria criminal. Trad. Paolo Capitanio. Campinas: Bookseller, 2001, p. 87 e ss.

14 Princípio unificador do sistema inquisitório. Sobre a definição de sistemas, ver: KANT, Immanuel. Crítica da razão pura. Trad. Manuela Pinto dos Santos e Alexandre Fradique Morujão. 4. ed. Lisboa: Fundação Calouste Gulbenkian, 1997, p. 657 e ss.

15 COUTINHO, Jacinto Nelson de Miranda. Introdução aos princípios gerais ..., p. 166.

16 BAPTISTA DA SILVA, Ovídio. Curso de processo civil. ..., v. I, p. 349. 
e daquela prudência que o tempo e o trato com os homens trouxeram aos práticos e aos juristas de muitos séculos. Nenhuma desvantagem em que os juízes os sigam ou em que as leis aconselhem a observância deles". ${ }^{17}$

Não há uma indicação temporal precisa que indique a data específica do fim da vigência deste sistema tarifário de avaliação das provas no processo. Alguns autores o identificam, na maioria das vezes, com o início do processo de humanização do Direito, em que há o declínio do antigo regime e uma prevalência das decisões pelos juízes, muito mais independentes e ligados aos ideais democráticos, que passam a viver sob uma racionalidade bastante diferenciada daquela que intensamente vigorava anteriormente e também pela modificação do conceito de verdade até então exposto.

MICHEL FOUCAULT, por exemplo, identifica o fim do antigo sistema das provas legais com a necessidade verificada pelo poder de punir de que, através das provas colhidas, se chegasse a um estado de certeza irrefutável, a fim de que a realidade do castigo efetivamente acompanhasse a realidade do delito, de acordo com meios válidos para todos. É o que ele chama de regra da verdade comum. O indivíduo deveria ser reputado inocente até que efetivamente se comprovasse que tinha praticado um delito e, para chegar a tal conclusão, o juiz deve usar não formas rituais, mas instrumentos comuns. "Agora, a prática penal vai-se encontrar submetida a um regime comum da verdade, ou antes a um regime complexo em que se misturam para formar a íntima convicção do juiz elementos heterogêneos de demonstração científica, de evidências sensíveis e de senso comum. A justiça penal, se conserva formas que garantem sua eqüidade, pode-se abrir agora às verdades de todos os ventos, desde que sejam evidentes, bem estabelecidas, aceitáveis por todos. O ritual judiciário não é mais em si mesmo formador de uma verdade partilhada. É recolocado no campo de referência dos discursos científicos, uma relação difícil e infinita, que a justiça penal hoje ainda não está apta a controlar. O senhor da justiça não é mais o senhor de sua verdade". ${ }^{18}$

FRANCO CORDERO, por sua vez, indica uma data precisa para o abandono do sistema das provas legais: o fim do Ancien régime, com o aparecimento (para o processo penal, especificamente), em 1808, do Code d'Instruction Crimininel. Vale dizer, momento em que os ideais iluministas estavam absolutamente em voga e a repulsa por todas as práticas judiciárias desumanas encontrava-se em seu apogeu. Almejavase, sobretudo, a adoção de um processo penal (especialmente) verdadeiramente justo e democrático, e a prática advinda da adoção do sistema tarifário não correspondia a este objetivo, pois estava ligada essencialmente à aceitação da tortura como meio de prova. ${ }^{19}$

\subsection{Fase sentimental ou da certeza moral do juiz}

Para NILO BAIRROS DE BRUM, esta fase teria surgido logo após a Revolução Francesa, como reação ao sistema da prova legal. ${ }^{20}$ Ao passo que para HELIO

17 TORNAGHI, Helio. Instituições de processo penal. ..., v. IV, p. 216.

18 FOUCAULT, Michel. Vigiar e punir. Trad. Raquel Ramalhete. 11. ed. Petrópolis: Vozes, 1994, p. 89.

19 Neste sentido, ver: CORDERO, Franco. Guida alla procedura penale. Torino: UTET, 1986.

20 BRUM, Nilo Bairros de. Requisitos retóricos ..., p. 55. 
TORNAGHI este é o sistema primitivo de todos os povos, como, por exemplo, do povo romano. ${ }^{21}$

Este é o chamado sistema da convicção íntima ou, para alguns, do livre convencimento. ${ }^{22}$ Neste sistema, o legislador silencia completamente quanto ao valor das provas. A sua admissibilidade e a sua avaliação são deixadas inteiramente ao arbítrio do magistrado. "A verdade jurídica reside por inteiro na consciência do juiz". ${ }^{23}$ A liberdade, assim, é total. Talvez este seja o seu maior problema, a sua grande falha.

O juiz decidirá única e exclusivamente baseado em sua íntima convicção (ex informata conscientia) e, por isso, não precisa motivar a sua decisão. O juiz não está limitado por qualquer regra prévia de avaliação, ditada pelo legislador. Ele é soberano e livre para formar a sua conviç̧ão, da forma que bem entender, sobre os fatos da causa. É exatamente o oposto do sistema tarifário de avaliação da prova.

Assim, "a conviç̧ão decorre não das provas, ou melhor, não só das provas colhidas, mas também do conhecimento pessoal do juiz, das suas impressões pessoais, e à vista destas lhe é lícito repelir qualquer ou todas as demais provas. Além do que não está obrigado a dar os motivos em que funda a sua convicção, nem os que o levaram a condenar ou absolver". ${ }^{24}$

MOACYR AMARAL SANTOS aponta dois grandes defeitos deste sistema. Para ele, a convicção íntima ofende dois princípios fundamentais de justiça: o de que ninguém pode ser condenado sem ser ouvido (ne inauditus condemnetur) e o da sociabilidade do convencimento. O primeiro porque contraria brutalmente o contraditório entre as partes, vital para o processo; o segundo porque a convicção, segundo ele, não pode decorrer simplesmente da apreciação subjetiva da prova pelo juiz: ele deve, ainda, demonstrar a todos as razões de seu convencimento, no sentido de que "os fatos e as provas submetidos aos seu juízo, se fossem submetidos à apreciação desinteressada de qualquer outra pessoa razoável, deveriam produzir, também nesta, a mesma convicção que produziram no juiz". ${ }^{25}$

Este sistema é usado, ainda, na maioria dos ordenamentos jurídicos, na instituição do Júri. E, segundo HELIO TORNAGHI, tal sistema também é utilizado nos tribunais de honra, onde estes existem (por exemplo, na Itália, em Portugal e na Alemanha). ${ }^{26}$

21 TORNAGHI, Helio. Instituições de processo penal. ..., v. IV, p. 212.

22 Esta diferença na nomenclatura pode-se verificar, por exemplo, entre MOACYR AMARAL SANTOS (Primeiras linhas ...) e HELIO TORNAGHI (Instituições ...).

23 MARQUES, José Frederico. Elementos de direito processual penal. Rio de Janeiro: Forense, v. II, 1961, p. 298.

24 SANTOS, Moacyr Amaral. Primeiras linhas de direito processual civil. ..., v. II, p. 383.

25 SANTOS, Moacyr Amaral. Primeiras linhas de direito processual civil. ..., v. II, p. 383.

26 TORNAGHI, Helio. Instituições de processo penal. ..., v. IV, p. 214. 


\subsection{Fase científica}

É o sistema vigente nos sistemas processuais contemporâneos. É também conhecido como o sistema do livre convencimento, ${ }^{27}$ da livre convicção, ${ }^{28}$ da persuasão racional, ${ }^{29}$ da livre apreciação da prova ou da prova livre. ${ }^{30}$ Nesta fase, "os juízes possuem capacitação técnica e podem socorrer-se do conhecimento de técnicos de outras áreas quando a prova depender de saberes alheios à sua capacitação". ${ }^{31}$ Alguns autores o vêem como um sistema misto, que mescla algumas características da convicção íntima e da prova legal. ${ }^{32}$

Para JORGE DE FIGUEIREDO DIAS, foram quatro fatores principais que permitiram a evolução para o sistema do livre convencimento: a) a elevação do júri como instituição competente para a apreciação da prova em processo penal no século XIX; b) a difusão dos métodos científicos de prova ${ }^{33}$ que permitiram reduzir a margem de erro na apreciação livre daquela; c) o deslocamento da base da compreensão do direito das normas gerais e abstratas para as circunstâncias concretas do caso; d) só uma livre valoração permite a apreciação da personalidade do acusado. ${ }^{34}$

Neste sistema (ou nesta fase), o juiz possui ampla liberdade na apreciação da prova, todavia tem o dever de fundamentar sua decisão com base nos elementos contidos nos autos (quod non est in actis non est in mundo). Vale dizer, para o seu convencimento deve o juiz se valer só daquilo que todos sabem (que está nos autos) e jamais (em tese) pode se valer de seu conhecimento privado. Isso porque, na esteira dos ensinamentos de HELIO TORNAGHI, ${ }^{35}$ a prova não é produzida apenas para o juiz, mas também (e em igual nível) para as partes do processo e para os outros juízes que possam vir a reapreciar a matéria em sede de recurso. Assim, "se o juiz sabe da existência de provas que não estão no bojo do processo, deve trazê-las, juntando documentos, determinando diligências, etc". ${ }^{36}$

O juiz deve pesar o valor das provas segundo aquilo que lhe pareça a melhor solução, devendo, porém, explicitar os motivos que o levaram a tal decisão. Como já dito, o juiz decide apenas com as provas dos autos, mas deve avaliá-las segundo o critério da crítica sã e racional. Isto é, nas palavras de JOSÉ FREDERICO MARQUES,

27 MARQUES, José Frederico. Elementos de direito processual penal. ..., v. II, p. 298.

28 TORNAGHI, Helio. Instituições de processo penal. ..., v. IV, p. 217.

29 SANTOS, Moacyr Amaral. Primeiras linhas de direito processual civil. ..., v. II, p. 384.

30 DIAS, Jorge de Figueiredo. Direito processual penal. ..., v. I, p. 198.

31 BRUM, Nilo Bairros de. Requisitos retóricos ..., p. 55.

32 Assim se manifestam FREDERICO MARQUES (Elementos ...) e OVÍDIO BAPTISTA DA SILVA (Curso ...).

33 Por isso conhecida como fase científica.

34 DIAS, Jorge de Figueiredo. Direito processual penal. ..., v. I, p. 200-201.

35 TORNAGHI, Helio. Instituições de processo penal. ..., v. IV, p. 217.

36 Este é o nosso sistema essencialmente inquisitório ... 
"o juiz deve decidir com relação à sã crítica, não tem a liberdade de raciocinar discricionariamente, arbitrariamente. O livre convencimento deve conjugar a lógica e a experiência, sem excessivas abstrações de ordem intelectual, mas observando sempre os preceitos e métodos que tendem a assegurar o mais acertado e eficaz raciocínio". ${ }^{37}$ Ou segundo JORGE DE FIGUEIREDO DIAS, "a liberdade de apreciação da prova é, no fundo, uma liberdade de acordo com um dever - o dever de perseguir a chamada verdade material -, de tal sorte que a apreciação há-de ser, em concreto, recondutível a critérios objectivos e, portanto, em geral susceptível de motivação e controlo". ${ }^{38}$ Ademais, deve o juiz, na sentença, na demonstração das razões de seu convencimento, tentar convencer a si mesmo e os outros da sua opção. Caso contrário, as partes recorrem e o Tribunal acaba por modificar a sua decisão.

A partir do exposto, pode-se concluir, num primeiro momento, que o livre convencimento não significa, em absoluto, anarquia na apreciação da prova, encontrando no dever de motivação da decisão o seu mais importante limite.

Por todos, remeter-se-á ao pensamento de D. SIRACUSANO, A. GALATI, G. TRANCHINA e E. ZAPPALÀ: “... Il principio resulta ancorato al dato probatorio, funziona nell'area riservata alla valuazione della prova, trova un suo limite nella motivazione. Ancorare il libero convincimento al dato probatorio significa circoscrivere la piattaforma su cui lo stesso può essere esercitato. Diceva PESSINA: 'il giudice è libero di credere o di non credere alle prove adotte, ma non può uscire dai confini legali, sian relativi al raccoglimento di esse, siano relativi alla loro disamina nella pubblica discussione'. Aggiunge oggi CORDERO: 'libero convincimento significa rifiuto delle prove a valuazione vincolata: ma la prova è pur sempre un atto regolato dal diritto, che anzitutto ne fissa le condizione di ammissibilità e i modi di formazione". ${ }^{39} \mathrm{E}$ continua: "Il giudice valuta la prova dando conto nella motivazione dei resultati acquisiti e dei criteri adottati. Il raccordo fra convincimento del giudice e obbligo di motivare in fatto appare sancito con suficiente precisione. Quest'obbligo funziona come preventiva remora da possibili arbitri, impegna a riflettere sui contenuti del giudizio (e sulle connesse proiezioni nella motivazione della sentenza) e riviene significativi addellati nelle disposizioni relative ai requisiti ed alla redazione della sentenza" ${ }^{40}$

37 MARQUES, José Frederico. Elementos de direito processual penal. ..., v. II, p. 299.

38 DIAS, Jorge de Figueiredo. Direito processual penal. ..., v. I, p. 202-203.

39 SIRACUSANO, D.; GALATI, A.; TRANCHINA, G.; ZAPPALÀ, E. Diritto processuale penale. Milano: Giuffrè, v. I, 1994, p. 389. Trad. da autora: "O princípio resulta ancorado ao fato probatório, funciona na área reservada à valoração da prova, encontra seu limite na motivação. Ancorar o livre convencimento ao fato probatório significa circunscrever a plataforma sobre a qual o mesmo pode ser exercitado. Dizia PESSINA: o juiz é livre para crer ou não crer nas provas adotadas, mas não pode sair dos limites legais, sejam relativos ao acolhimento delas, sejam relativos ao exame delas na discussão pública. Acrescenta hoje CORDERO: livre convencimento significa recusa das provas à valoração vinculada: mas a prova é tão-somente um ato regulado pelo direito, que antes de mais nada lhe fixa as condições de admissibilidade e modos de formação".

40 SIRACUSANO, D.; GALATI, A.; TRANCHINA, G.; ZAPPALÀ, E. Diritto processuale penale. Milano: Giuffrè, v. I, 1994, p. 391. Trad. da autora: "O juiz valora a prova dando conta na motivação dos 
Além desse, outros limites, em verdade, impõem-se ao livre convencimento. Por exemplo, o juiz não pode (ou, ao menos, não poderia) basear sua convicção em provas produzidas no processo em desacordo com os princípios constitucionais do contraditório, como o interrogatório do acusado na fase do inquérito policial. O juiz não poderá dispensar as regras legais quanto à forma dos atos jurídicos, sob pena de desobediência aos mandamentos legais do direito processual penal.

Neste passo, em última análise, a livre apreciação da prova acaba por abranger todos os chamados momentos da prova: a sua proposição, a sua admissão, a sua produção e a sua avaliação, uma vez que só poderá ser devidamente valorada pelo magistrado a prova legalmente admitida nos autos, livre de qualquer vício. "La disciplina del procedimento probatorio, volta a regolamentare il libero convincimento del giudice che si esprime nella decisione, si sviluppa su tre distinte direttive. Essa contiene, in primo luogo, le regole per l'assunzione dei mezzi di prova, con la prescrizione di forme, la posizione di limiti all'allegazione, la determinazione delle modalità di acquisizione. Individua, in secondo luogo, i criteri che debbono essere seguiti dal giudice nella valutazione della prova. Fa obbligo, in terzo luogo, al giudice di dare conto delle sue scelte attraverso la motivazione". ${ }^{41}$

Finalmente, vale ressaltar o pensamento de JACINTO NELSON DE MIRANDA COUTINHO ${ }^{42}$ quando alerta que é inevitável admitir que o princípio do livre convencimento pode ser manipulado pelo julgador, motivo pelo qual se torna deveras importante a consciência do juiz neste momento, para que a garantia constitucional do art. 93, IX, não seja desrespeitada. Sobre o tema, faz menção aos ensinamentos de NILO BAIRROS DE BRUM: "Geralmente, chegado o momento de prolatar a sentença penal, o juiz já decidiu se condenará ou absolverá o réu. Chegou a essa decisão (ou tendência a decidir) por vários motivos, nem sempre lógicos ou derivados da lei. Muitas vezes, a tendência de condenar está fortemente influenciada pela extensão da folha de antecedentes do réu ou, ainda, pela repugnância que determinado delito (em si) provoca no espírito do juiz. Por outro lado, o fiel da balança pode ter pendido para a absolvição em razão da grande prole do réu ou em virtude do fato de estar ele perfeitamente

resultados obtidos e dos critérios adotados. A conexão entre convencimento do juiz e a obrigação de motivar de fato aparece decretada com precisão suficiente. Esta obrigação funciona como prevenção da incerteza de possíveis arbítrios, obriga a refletir sobre o conteúdo do julgamento (e sua respectiva projeção na motivação da sentença) e vem significativamente demonstrada nas disposições relativas aos requisitos e à redação da sentença".

41 DALIA, Andrea Antonio; FERRAIOLI, Marzia. Manuale di diritto processuale penale. Padova: CEDAM, 1999, p. 624. Trad. da autora: "A disciplina do procedimento probatório, destinada a regulamentar o livre convencimento do juiz que se exprime na decisão, desenvolve-se em três diretivas diferentes. Ela contém, em primeiro lugar, as regras para a admissão dos meios de prova, com a prescrição de forma, a posição dos limites das alegações, a determinação da modalidade de aquisição. Individualiza, em segundo lugar, os critérios que devem ser seguidos pelo juiz na valoração da prova. Obriga, em terceiro lugar, o juiz a dar conta das suas escolhas através da motivação".

42 COUTINHO, Jacinto Nelson de Miranda. Introdução aos princípios gerais ..., p. 197. 
integrado na comunidade ou, ainda, pelo fato de que o delito cometido nenhuma repugnância causa ao juiz, o que o faz visualizar tal figura penal como excrescência legislativa ou um anacronismo jurídico. Sabe o julgador, entretanto, que essas motivações não seriam aceitas pela comunidade jurídica sem uma roupagem racional e tecnicamente legítima. Se declarar francamente que condena o réu em razão de seus péssimos antecedentes ou que o absolve porque é trabalhador e tem muitos filhos, sua sentença fatalmente será reformada por falta de base jurídica. (...) Buscará, então, o julgador outro caminho que pode ser através da avaliação da prova ou por meio da interpretação da norma. Geralmente, pelo menos entre nós, os juízes preferem o primeiro caminho, já que a prova é produzida longe dos tribunais e a possibilidade de controle é mais difícil. (...) Mas o julgador tem de justificar sua escolha: tem de convencer que elegeu a melhor prova. Surge aqui o primeiro requisito retórico da sentença, que não é outro senão o da verossimilhança fática. Trata-se de um efeito de verdade". ${ }^{43}$

\section{O SISTEMA DE AVALIAÇÃO DA PROVA ADOTADO NO PROCESSO PENAL BRASILEIRO}

No Brasil, e a doutrina é unânime neste sentido, adotou-se o princípio do livre convencimento, a teor do disposto no art. 157 do Código de Processo Penal, que deve ser lido juntamente com o art. 93, IX, da Constituição Federal. ${ }^{44}$

Assim, conforme tudo o que acabou de ser dito, no sistema processual penal brasileiro, o juiz valora livremente, da forma que melhor entender, as provas colhidas durante a instrução criminal e a partir dessa valoração forma o seu convencimento, devendo, após, demonstrar explicitamente as razões de sua escolha. Em tese, não haveria que se falar em hierarquia de provas e tampouco em decisões baseadas única e exclusivamente na consciência do juiz (ou jurados).

Ocorre que esta não é a realidade brasileira. Críticas ferrenhas vêm sendo feitas ao longo de várias décadas por grandes juristas brasileiros referentes à manutenção, em algumas hipóteses, do tarifamento de provas.

Cabe aqui ressaltar, por oportuno, que a hierarquia das provas pode ser enxergada sob dois aspectos principais. O primeiro diz com a hierarquia determinada em lei, à qual efetivamente se destinam as críticas acima mencionadas. E o segundo com a hierarquia das provas determinada por cada magistrado, pelo juiz como pessoa, de acordo com a sua escala de valores, a qual é inerente a todo ser humano e que, apesar de se tratar de um ponto teoricamente inacessível a um controle externo (não se pode obrigar alguém a pensar de uma certa maneira ou de outra), é esta mesma escala de

43 BRUM, Nilo Bairros de. Requisitos retóricos ..., p. 72-73.

44 Art. 157, CPP: "O juiz formará sua convicção pela livre apreciação da prova".

Art. 93; IX, CF: "Todos os julgamentos dos órgãos do Poder Judiciário serão públicos, e fundamentadas todas as decisões, sob pena de nulidade, podendo a lei, se o interesse público o exigir, limitar a presença, em determinados atos, às próprias partes e a seus advogados, ou somente a estes." 
valores que vai ser a grande determinante do livre convencimento do juiz, razão esta da preocupação de muitos operadores do direito no que se refere à garantia constitucional das motivações das decisões e a um possível (ou impossível) controle dessa atividade, de forma a efetivar o direito assegurado pelo texto constitucional. Neste trabalho, aterse-á apenas ao primeiro aspecto em virtude da maior complexidade do segundo, que exigiria um espaço muito maior para a sua discussão.

Dois são os grandes exemplos que comprovam a existência de um resquício do tarifamento legal no sistema do Código de Processo Penal brasileiro. São eles os arts. 155 e 158 do Código de Processo Penal.

Reza o art. 155 do CPP: "No juízo penal, somente quanto ao estado das pessoas, serão observadas as restrições à prova estabelecidas na lei civil". Aqui pode-se perceber que o princípio de liberdade probatória, durante muito tempo defendido por aqueles que acreditavam que no processo penal vigia o princípio da verdade material, não é, contudo, absoluto, prevendo a lei que, quanto ao estado das pessoas, devem ser observadas as restrições à prova estabelecidas na lei civil. Assim, por exemplo, o casamento prova-se pela certidão do registro (art. 202 do CC), a menoridade penal pela certidão de nascimento, embora pacificamente se entenda que a substitui qualquer documento idôneo (Súmula $\mathrm{n}^{\circ} 74$ do $\mathrm{STJ}$ ). Esta regra refere-se, ainda, às chamadas questões prejudiciais heterogêneas que dizem respeito ao estado civil das pessoas (art. 92 do (PP), as quais, no sistema brasileiro, são resolvidas obrigatoriamente no juízo cível (prejudicialidade civil absoluta) e cuja decisão será inteiramente acolhida pelo juízo penal.

Dessa forma, em sendo restrita a própria produção da prova no caso do estado civil das pessoas, certo é que o legislador teve também a intenção de interferir no livre convencimento do juiz no que tange ao tema. Vale dizer, o juiz não pode, ainda que disponha de prova suficiente produzida no juízo penal, decidir de forma contrária às restrições estabelecidas na lei civil, ao menos no que tange ao estado das pessoas.

Há, ainda, a regra prevista no art. 158 do CPP: "Quando a infração deixar vestígios, será indispensável o exame de corpo de delito, direto ou indireto, não podendo supri-lo a confissão do acusado". E a falta do corpo de delito nestas hipóteses gera a nulidade absoluta do processo, a teor do art. 564, III, $b$, do CPP, salvo se não foi possível a sua realização por haverem desaparecidos os vestígios, caso em que apenas a prova testemunhal poderá suprir a falta da perícia (art. 167 do CPP).

JOSÉ FREDERICO MARQUES, ao tratar deste dispositivo legal, afirma claramente que, "na verdade, forma do sistema da prova legal, só um Código como o nosso, em que não há a menor sistematização científica, pode manter a exigibilidade do auto de corpo de delito sob pena de considerar-se nulo o processo. Que isso ocorresse ao tempo da legislação do Império, ainda se compreende. Mas que ainda se consagre tal baboseira num estatuto legal promulgado em 1941, eis o que se não pode explicar de maneira razoável". ${ }^{45} \mathrm{E}$ continua, fazendo referência aos ensinamentos de COSTA

45 MARQUES, José Frederico. Elementos de direito processual penal. Rio de Janeiro: Forense, v. II, 1961, p. 364-365. 
MANSO: "Parece-me claro que êsse documento não constitui uma formalidade substancial do processo. É simples meio de prova, que (...) pode ser suprido por provas de outro gênero. A falta ou defeito do auto, portanto, deve dar lugar, não a que o processo seja anulado, mas a que recorra o juiz a outros elementos de convicção, e, não os encontrando suficientes, declare não provado o crime" ${ }^{46} \mathrm{E}$ conclui dizendo: "Da conjugação dêsses três dispositivos ${ }^{47} \mathrm{o}$ que se infere é que o auto ou exame de corpo de delito deve ser realizado em todo o delito que deixa vestígios, sob pena de nulidade. Por outra parte, não pode a confissão supri-lo; e ante a impossibilidade de exame dos vestígios do crime, a prova testemunhal é a única que o pode suprir. Isto significa que se o réu confessar o crime e a confissão vier a ser corroborada por indícios, não pode êle ser julgado, pois o processo estará nulo por falta de exame de corpo de delito direto ou indireto". ${ }^{48}$

De fato, se o sistema de avaliação da prova adotado pelo sistema brasileiro foi o do livre convencimento, total razão assiste ao ilustre doutrinador JOSÉ FREDERICO MARQUES quando critica essa evidente hierarquia de provas que é imposta ao julgador, tal como se se estivesse sob o sistema da prova legal.

Para alguns autores, como ANTONIO MAGALHÃES GOMES FILHO, na verdade, essas regras probatórias como a do art. 158 têm como finalidade evitar que o convencimento do juiz ou dos jurados leve a conclusões arriscadas, por conta de uma reconstrução equivocada dos fatos que possa vir a ser por eles realizada na falta do exame de corpo de delito. Diz ele que "tal cautela não constitui, como pareceu a JOSÉ FREDERICO MARQUES, uma baboseira que só encontraria guarida no sistema da prova legal, ou, como afirmado em recente pronunciamento jurisprudencial, ${ }^{49}$ cláusula incompatível com o processo penal moderno, mas importante garantia voltada à obtenção da verdade processual, que consubstancia exemplo claro de uma inadmissibilidade do meio de prova, com o objetivo de evitar erros que poderiam resultar na indiscriminada admissão de qualquer prova para demonstração da própria existência do fato que deixou rastros materiais". ${ }^{50}$

É bem verdade que a grande preocupação atual dos processualistas em geral é fazer com que sejam respeitadas todas as garantias fundamentais do indivíduo, mormente aquelas assecuratórias de sua liberdade. Mas, com o devido respeito, é mister se

46 MARQUES, José Frederico. Elementos de direito processual penal. ..., v. II, p. 365.

47 Aqui o autor se refere aos arts. 158, 167 e 564, III, $d$, todos do CPP.

48 MARQUES, José Frederico. Elementos de direito processual penal. Rio de Janeiro: Forense, v. II, 1961, p. 365-366.

49 O julgado a que se refere o autor é de origem do Superior Tribunal de Justiça, RHC 2.454-2/RN, Rel. Min. LUIZ VICENTE CERNICCHIARO. Ementa: "A Constituição da República resguarda serem admitidas as provas que não forem proibidas por lei. Restou, assim, afetada a cláusula final do art. 158, $\mathrm{CPP}$, ou seja, a confissão não ser idônea para concorrer com o exame de corpo de delito. No processo penal moderno, não há hierarquia de provas, nem provas específicas para determinado caso. Tudo o que lícito for, idôneo será para projetar a verdade real" (RT 694/392-2).

50 GOMES FILHO, Antônio Magalhães. Direito à prova no processo penal. São Paulo: Revista dos Tribunais, 1997, p. 97-98. 
reconhecer que existe um claro tarifamento de provas nas hipóteses das provas periciais. Se é apenas um último resquício da prova tarifária ou um instrumento de efetivação de garantias constitucionais, essa é uma discussão que não deve aqui ser iniciada. Contudo é certo que hierarquia existe entre as provas.

Entretanto, parece evidente que nos dois exemplos citados, especialmente no segundo (talvez isso se verifique em toda codificação processual penal), como não poderia deixar de ser, o legislador optou por dar maior valor à prova pericial do que às demais, com fundamento, ainda que inconsciente, no segundo aspecto da hierarquia das provas anteriormente mencionado - a hierarquia decorrente da escala de valores do indivíduo, no caso o legislador. Essa preferência pela prova científica, não se pode negar, verifica-se em cada um de nós, e é quase uma unanimidade. E essa "força" desse meio de prova, consoante adverte MICHEL FOUCAULT, provavelmente deriva do fato de que esses discursos científicos funcionam na instituição judiciária como discursos de verdade, porque dotados de estatuto científico, ou como discursos formulados, e formulados por pessoas qualificadas pertencentes a uma instituição científica. ${ }^{51}$ Assim, para ele, os relatórios periciais têm, com relação aos demais elementos de demonstração judiciária, certa prevalência: "não são provas legais no sentido em que o direito clássico as entendia ainda no fim do século XVII, mas são enunciados judiciários privilegiados que comportam presunções estatutárias de verdade, presunções que lhe são inerentes, em função dos que as enunciam. Em suma, são enunciados com efeitos de verdade e de poder que lhes são específicos: uma espécie de supralegalidade de certos enunciados na produção da verdade judiciária". ${ }^{2}$

Finalmente, há também no sistema processual penal brasileiro hipóteses em que no julgamento de um determinado acusado o convencimento do julgador se forma unicamente através da convicção íntima - é o caso dos veredictos apresentados pelo Conselho de Sentença no Tribunal do Júri. Os jurados, ao responder os quesitos formulados, dizem apenas "sim" ou "não", e não explicitam jamais o porquê. E a proteção à instituição do Júri é bastante considerável no Brasil, consistindo em uma das instituições mais respeitadas pela sociedade (apesar de os julgamentos serem baseados na convicção íntima). Reconhece o art. $5^{\circ}$, XXXVIII, $b$ e $d$, da Constituição Federal, que é assegurado ao júri o sigilo das votações e também a soberania dos veredictos. Ademais, tal é essa soberania do Tribunal do Júri que se o réu apela da decisão do Conselho de Sentença com supedâneo no art. 593, III, $d$, do Código de Processo Penal (decisão manifestamente contrária à prova dos autos), o máximo que poderá fazer o Tribunal é remeter o acusado a um novo julgamento pelo Tribunal do Júri, e nunca decidir sobre o mérito do caso penal (a não ser naquelas hipóteses de revisão criminal, em que o Tribunal poderá absolver o réu).

Por fim, dispõe o art. 493 do CPP que a sentença será fundamentada, salvo quanto às conclusões que resultarem das respostas aos quesitos. Isso significa dizer

51 FOUCAULT, Michel. Os anormais. Trad. Eduardo Brandão. São Paulo: Martins Fontes, 2001, p. 08. 
que o juiz presidente, após a apresentação do veredicto pelos jurados, fará apenas a aplicação da pena ao condenado, atividade esta que deverá ser devidamente fundamentada, sob pena de nulidade. A condenação, em si, não precisa ser motivada, pois realizada pelo Conselho de Sentença.

Destarte, os jurados, ao decidirem sobre o destino daquele acusado, sobre o desfecho de um determinado caso penal, não precisam (e nunca o fazem) demonstrar as razões de seu convencimento, valorando as provas apenas de acordo com suas consciências, suas íntimas convicções.

\section{CONCLUSÃO}

A partir de todo o exposto, o que se pode concluir, por evidente, é que não há um único sistema de valoração das provas no processo penal brasileiro. Pelo contrário, consoante se pôde ver, ao mesmo tempo é possível verificar características dos três sistemas: prova legal, convicção íntima e livre convencimento. E esse era exatamente o objetivo deste trabalho: demonstrar (e nada além disso) que existe a convivência entre os três sistemas (ou ao menos entre algumas características dos três sistemas) no ordenamento processual penal, ou pelo menos não há a adoção de um sistema puro de avaliação das provas, na medida em que não se pode afirmar, com propriedade, que só um deles vige no sistema processual penal brasileiro. Há que se afastar aquela idéia falsa de que apenas o livre convencimento faz parte da realidade jurídica brasileira. É preciso tomar consciência dessa realidade e, somente a partir daí, poder-se-á começar a pensar em modificações (ou não, quem sabe) do sistema processual penal brasileiro, com vistas a um processo penal cada vez mais democrático e efetivador das garantias processuais e constitucionais.

\section{REFERÊNCIAS BIBLIOGRÁFICAS}

AMORIM, Manoel Carpena. Exame de corpo de delito e o princípio do livre convencimento. In: Revista de Direito Renovar. Rio de Janeiro: Renovar, v. 1, p. 45-52, jan./abr. 1995.

BAPTISTA DA SILVA, Ovídio. Curso de processo civil. São Paulo: Saraiva, v. I, 2000.

BARBOSA MOREIRA, José Carlos. O juiz e a prova. In: Revista de Processo. São Paulo: Revista dos Tribunais, ano IX, n. 35, p. 178-184, abr./jun. 1984.

BRUM, Nilo Bairros de. Requisitos retóricos da sentença penal. São Paulo: Revista dos Tribunais, 1980

CASTIGLIONE, Theodolindo. O livre convencimento do juiz e a hierarquia das provas. In: Revista dos Tribunais. São Paulo: Revista dos Tribunais, ano 51, v. 315, p. 586-595, jan. 1962. CORDERO, Franco. Guida alla procedura penale. Torino: UTET, 1986.

. Procedura penale. 3. ed. Milano: Giuffrè, 1995.

COUTINHO, Jacinto Nelson de Miranda. Introdução aos princípios gerais do processo penal brasileiro. In: Revista da Faculdade de Direito. Curitiba: UFPR, ano 30, n. 30, p. 163-198, 1998.

DALIA, Andrea Antonio; FERRAIOLI, Marzia. Manuale di diritto processuale penale. Padova: CEDAM, 1999. 
DALL'AGNOL, Antônio. Comentários ao código de processo civil. São Paulo: Revista dos Tribunais, v. 2, 2000.

DIAS, Jorge de Figueiredo. Direito processual penal. Coimbra: Coimbra Editora, v. I, 1981. FOUCAULT, Michel. Os anormais. Trad. Eduardo Brandão. São Paulo: Martins Fontes, 2001. . Vigiar e punir. Trad. Raquel Ramalhete. 11. ed. Petrópolis: Vozes, 1994.

GOMES FILHO, Antônio Magalhães. Direito à prova no processo penal. São Paulo: Revista dos Tribunais, 1997.

KANT, Immanuel. Crítica da razão pura. Trad. Manuela Pinto dos Santos e Alexandre Fradique Morujão. 4. ed. Lisboa: Fundação Calouste Gulbenkian, 1997.

MALATESTA, Nicola Framarino Dei. A lógica das provas em matéria criminal. Trad. Paolo Capitanio. Campinas: Bookseller, 2001.

MARQUES, José Frederico. Elementos de direito processual penal. Rio de Janeiro: Forense, v. II, 1961.

PATTI, Salvatore. Libero convincimento e valuazione delle prove. In: Rivista di Diritto Processuale. Padova: CEDAM, ano XL, n. 3, p. 481-519, 1985.

SANTOS, Moacyr Amaral. Primeiras linhas de direito processual civil. São Paulo: Saraiva, v. II, 1985.

SILVA, Germano Marques da. Curso de processo penal. Lisboa: São Paulo, v. I, 1994.

SIRACUSANO, D. et al. Diritto processuale penale. Milano: Giuffrè, v. I, 1994.

TORNAGHI, Helio. Instituições de processo penal. Rio de Janeiro: Forense, v. IV, 1959. 